\title{
Legal Policy of the Government of Indonesia for the Protection of Non-Permanent Workers' Rights
}

\author{
${ }^{1}$ Jelly Leviza, ${ }^{2} \mathrm{~T}$. Keizerina Devi \\ 1,2 Department of International Law, University of Sumatera Utara, Indonesia
}

\begin{abstract}
Legal protection against a daily work is very urgent today given the increasing number of them. Governments have an obligation to ensure the protection of the rights of them. This study discusses two subjects. The first is the inventory of labour rights according to the constitution and rules of normative and the implementation for daily work. The second is the substance of the government's policy to accommodate the protection of the rights of workers based on the Ministry of Manpower and Transmigration Republic of Indonesia Number: Kep.100 / Men/VI/2004 about the Provisions in the Implementation of Given Time Employment Agreement. The purpose of this study was to determine the protection of the constitutional and normative rights for daily workers. Next to determine the legal policy of the Indonesian government in providing protection to daily workers through Ministerial Decree No. 100/2004. Normative methods used to analyze the legal norms applicable in Indonesia governing the protection of daily workers. Based on this method, the portion of the protection of the rights of workers will be known. The results of this research are that the rights of an employee still do not fulfil the rights of workers constitutively and normatively. Government policy in the protection of daily workers was still not enough to provide legal certainty, usefulness, and fairness for workers. The government's policy regarding the rights of daily workers still needs to be improved in order to accommodate the rights of daily workers.
\end{abstract}

Keywords: Daily workers, Government policy, Legal protection

\section{Introduction}

Manpower development in Indonesia is directed to improve the quality and its contribution to national development and to protect the rights and interests of workers in accordance with human dignity (Salomo Perangin-angin, 2008). Labour law in Indonesia has the objective to implement social justice through the protection of workers against employers' power (Riki, Kurnia, Susanti, 2014).

The status of non-permanent employees is not permanent employees. However, nonpermanent employees nor status as an employee in a period of training (Soepomo, 1974).

A non-permanent worker is a person who does a certain job in terms of timing, volume, and wages based on his presence. It refers to The Rule of the Ministry of Manpower and Transmigration Republic of Indonesia No. Kep-100/Men/VI/2004 about implementing provisions to the Employment Agreements with Certain Time.

Legal protection against non-permanent workers is important because of the lack of knowledge and their understanding of the rules of law as a result of low educational background. In addition, it is the absence of non-permanent union has resulted in the absence of a forum that 
is expected to fight for their rights when an industrial dispute occurred. Many non-permanent workers do not understand the rules of the applicable law. Therefore, the existence of trade unions become so important to them (Lepas, Dalam).

In addition to the various reasons stated above, legal protection for non-permanent workers is urgent because of the increasing number of them in various fields, one of them on the field of oil palm plantations. Oil palm plantations in Indonesia currently has an area of 14.3 million hectares. While the number of workers employed in oil palm plantations has reached 10.4 million people, where 70 percent of the workers' status as a non-permanent worker. This is noteworthy because, at the time when profits and success enjoyed by oil palm planters, the conditions experienced by workers was very worrying (Pierewan, 2016).

Non-permanent workers are often faced with uncertainty in their work relationship. Therefore, the government needs to perform justice to the protection of the parties whose position is weak. Poor financial conditions faced by non-permanent workers have made them among others, must involve couples and their children to work to help the family finances, do extra work to depress household expenditure (Agusmidah, 2011).

A form of protection that should be given to non-permanent workers is a social security of employment. Under the provisions of Act No. 24 of 2011 concerning Social Security Agency, the employer shall register himself and Workers as Participant to the Social Security Agency. If the above obligations are not implemented, then the employer may be subject to administrative sanctions (Tobing, 2016).

\section{Material and Methods}

This paper uses the method of normative legal research methods that focus on the study of the norms of law contained in the legislation. The legal norms applicable in this context are the norms of labour law contained in the legislation. Normative Study conducted from the norms of employment law in the constitution and legislation, the latter will refer to the ministerial decision which specifically regulates non-permanent employees.

\section{Literature Review}

\subsection{The Rights of Workers Under the Constitution and Regulations in Indonesia and} the Rights of Non-Permanent Workers

Provisions in the Employment Agreement for specific time periods outlined in Act No. 13 of 2003 on Manpower of Article 56 through Article 59, which at the end of Article 59, namely in paragraph (8) states that: "Decree of the Minister shall govern other things that are not under this section ". The provision establishes the basis for the rule of Minister of Manpower and Transmigration Republic of Indonesia Kep-100/Men/VI/2004 concerning the Implementing Provisions for Certain Time Employment Agreement.

The employment agreement for non-permanent workers contained in article 10 to article 12 of Ministerial Decree No. 100 of 2004. The Employment Agreement freelance excludes some general provisions of the Employment Agreement Specific Time (PKWT), which in the Employment Agreement freelance contained several conditions, including:

1. The agreement was implemented for certain jobs that vary in terms of time and volume of work, and wages are based on attendance;

2. The agreement provided that the term work is done for less than 21 days in a month;

3. If an employee has worked for 21 worker-days or more, for three consecutive months or more, then freelance employment covenant is turned into Employment Agreement for Time Indefinite. 
In the hierarchy, a legal product should be stated in advance relating to the rights of workers, in general, is UUD 1945 which regulated the constitutional rights of workers. Furthermore, workers' rights were published in the form of legislation. The description in table form below will illustrate the workers' rights in a constitutional and normative as mentioned above.

Table 1: Constitutive Worker Rights Based on the 1945 Constitution

\begin{tabular}{|l|l|c|}
\hline & The types of Constitutive rights of Worker & Article \\
\hline & $\begin{array}{l}\text { Right to association and assembly, the right to express thoughts verbally } \\
\text { or in writing }\end{array}$ & $28(2)$ \\
\hline $\begin{array}{l}\text { The right to life and to defend livelihood. } \\
\text { Right to fulfil the basic needs, the right to educate and benefit from science } \\
\text { prosperity of mankind. Right to advance themselves in the fight for the } \\
\text { rights collectively to build a society, nation, and state. }\end{array}$ & $28 \mathrm{C}$ \\
\hline $\begin{array}{l}\text { Right to recognize, secure, protect, and legal certainty and equal } \\
\text { treatment before the law. Right to employ and earn rewards, fair } \\
\text { treatment and decent in the employment relationship. }\end{array}$ & $28 \mathrm{D}$ \\
\hline $\begin{array}{l}\text { Rights to work. The right to freedom of association, assembly, and } \\
\text { expression }\end{array}$ & $\begin{array}{l}\text { The right to live of physical and spiritual, reside and get a good ambience } \\
\text { and medical care. The right to development of self as a human being. }\end{array}$ & $28 \mathrm{H}$ \\
\hline
\end{tabular}

The constitutional rights of workers as contained in the above table is substantively the Indonesian human rights in general, but it also covers the rights of workers. In particular, workers' fundamental rights stipulated in Law No. 13 Year 2003 as presented in tabular form below.

Table 2: Normative Rights of Workers Based on Labor Law No. 13 Year 2003

\begin{tabular}{|l|l|c|}
\hline & Normative Rights of Workers & Article \\
\hline & Right to equal opportunity without discrimination to get a job & 5 \\
\hline & $\begin{array}{l}\text { Right to get equal treatment with no discrimination from employers } \\
\text { interests, and abilities by vocational training. }\end{array}$ & 6 \\
\hline & $\begin{array}{l}\text { The right to equal opportunities to follow the job training in their } \\
\text { respective sectors }\end{array}$ & $12(3)$ \\
\hline $\begin{array}{l}\text { The right to obtain recognition of the competence of work after } \\
\text { following vocational training organized vocational training } \\
\text { institutions of government, private or training in the workplace. }\end{array}$ & 23 \\
\hline $\begin{array}{l}\text { The right to recognition of job competence and qualifications of the } \\
\text { company or the certification body after taking part in an internship } \\
\text { program }\end{array}$ & $\begin{array}{l}\text { Rights of the heirs of the workers to get their rights in accordance } \\
\text { with the legislation in force or the rights set out in the employment }\end{array}$ & 61 (5) \\
\hline
\end{tabular}




\begin{tabular}{|c|c|}
\hline $\begin{array}{l}\text { agreement, company precepts or collective agreements if the worker } \\
\text { dies }\end{array}$ & \\
\hline $\begin{array}{l}\text { Rights to protection according to the type and degree of disability } \\
\text { for workers with disabilities }\end{array}$ & 72 \\
\hline $\begin{array}{l}\text { Rights of young workers to the workplace apart from a workplace } \\
\text { that adult workers. }\end{array}$ & $76(1)(2)$ \\
\hline $\begin{array}{l}\text { Rights of women workers aged less than } 18 \text { years old and pregnant } \\
\text { women not to work in the evenings }\end{array}$ & $76(3)$ \\
\hline $\begin{array}{l}\text { Rights of women workers on nutritious foods and beverages, morals, } \\
\text { and safety while at work when working night }\end{array}$ & $76(4)$ \\
\hline $\begin{array}{l}\text { Rights of women workers who work between 23:00-05:00 on } \\
\text { transport shuttle }\end{array}$ & $\begin{array}{l}77(2) \\
\text { point a }\end{array}$ \\
\hline $\begin{array}{l}\text { Right not to work over } 7 \text { (seven) hours a day, } 40 \text { (forty) hours in } \\
\text { six (6) days in } 1 \text { (one) week }\end{array}$ & $\begin{array}{l}77(2) \\
\text { point } b\end{array}$ \\
\hline $\begin{array}{l}\text { Right to work not exceed eight ( } 8 \text { ) hours a day and } 40 \text { (forty) hours } \\
\text { for } 5 \text { (five) days in } 1 \text { (one) week }\end{array}$ & $78(2)$ \\
\hline Right to overtime pay when working overtime & $79(1)$ \\
\hline Right to time off and leave to workers & 80 \\
\hline Right to practice their religion required by his religion & $81(1)$ \\
\hline $\begin{array}{l}\text { Right to menstrual leave on the first day and the second at the time } \\
\text { of menstruation }\end{array}$ & $81(1)$ \\
\hline $\begin{array}{l}\text { Right to maternity leave for } 1.5 \text { months before the time at which } \\
\text { they and } 1.5 \text { months after birth, according to calculations } \\
\text { obstetrician or midwife }\end{array}$ & $82(2)$ \\
\hline $\begin{array}{l}\text { Right to leave due to miscarriage for } 1.5 \text { (one-half) months or in } \\
\text { accordance with the certificate obstetrician or midwife }\end{array}$ & 83 \\
\hline Rights of women workers to breastfeed her child & 84 \\
\hline $\begin{array}{l}\text { Right to full compensation for the use of his right to take a break } \\
\text { refers to Article } 79 \text { (2) b, c, and d, Article } 80 \text { and Article } 82\end{array}$ & 86 \\
\hline $\begin{array}{l}\text { Right to: } \\
\text { a. Occupational Health and Safety; } \\
\text { b. Moral and decency; } \\
\text { c. Perlakuan following human dignity and religious values. }\end{array}$ & $87(1)$ \\
\hline $\begin{array}{l}\text { Right to safety and health management system integrated working } \\
\text { with the company's management system. }\end{array}$ & $88(1)-98$ \\
\hline Right to income that meets a decent livelihood for humanity & 99 \\
\hline Right to obtain social security & 104 \\
\hline Right to form and join trade unions/labour unions. & 104 \\
\hline Right to strike & 137 \\
\hline $\begin{array}{l}\text { Right to severance pay, gratuity, and compensation in the event of } \\
\text { layoffs }\end{array}$ & $\begin{array}{l}156,157 \\
164-168, \\
172 .\end{array}$ \\
\hline $\begin{array}{l}\text { Right of workers filed a lawsuit settlement institution if they do not } \\
\text { accept layoffs }\end{array}$ & 161 \\
\hline
\end{tabular}

The arrangement of the Employment Agreement Specific Time in the Rule No.13 Year 2003 on Manpower can cause ambiguity in interpretation while formulating employment contract, whether by period or by completion of the work. Things that need to be determined to be related legal regulation of non-permanent workers are the occupational category of permanent 
and temporary; categories of core and non-core work; Terms of the extension and renewal PKWT and strict sanctions for violations of the points above (Pelatihan Hakim, 2013).

Based on the entire conceptual description above, the protection which must be realized is through decent wages for life, protection of job security and social security protection of labour justice, given the nature of the non-permanent employees having jobs that are not fixed.

Analysis of the substance of Government Policy to Protect Workers' Rights/Labor freelance Through Decree 100/Men /VI/2004.

If seen from the shape Decree \# 100/Men/VI/2004 is not yet precise enough because the laws that form "Decision" both Regeling (set) and that is beschikking (policy) is a special effect or internal based attributive authority. The consequence of the above, the Decree \# 100/Men/VI/2004 should apply only internally within the Ministry of Employment and does not apply in general to the community. A more accurate form of legal products such as the "Regulations" because the regulations may generally apply to the whole society is based on the authority of attribution or delegation of authority from legislation. A legal product is also the more appropriate form of regulation in accordance with Law No. 12 Year 2011 on the Establishment of Legislation.

Other provisions noteworthy is PKHL complying with the provisions of Article 10 paragraph (1) and (2) are excluded from the provisions of the general PKWT period not exceeding three years, as determined by the provisions of Article 11 Kepmenakertrans RI $100 \mathrm{Kep} /$ Men / VI /2004. This provision opens opportunities for casual labour status that can be applied forever, as long as it is less than 21 days in a month. Working hours may be applied together with permanent workers even more.

Referring to Article 77 of Law No. 13 of 2003, the working time to PKWTT and PKWT is 40 hours a week, seven (7) hours a day if time work six (6) days a week, or eight (8) hours a day when the working time five days a week. In general, for PKWTT and PKWT: one month is 30 days minus four days off (Sunday) so that workers will normally work only 26 days, while for PKHL it is 21 days. So, the working time of workers PKWTT and PKWT (daily paid workers) in one (1) month of the difference is only five days, while the rights between the two are very significantly different that produces injustice and inequality.

PKHL does not get any social security from employers as well as workers who were tied with PKWTT and PKWT. Based on the research, Christina noted that daily paid workers no BPJS Employment included as participants or BPJS so that no one can guarantee if the worker had an accident, illness, death, or old age. Whereas social security protection rights of all workers' employment are guaranteed by law.

If viewed in terms of formal requirements, PKWTT need not be registered to the relevant agencies, to PKWT registered and individual nature. As for PKHL registration is not an individual but a mass character, it only lists the daily paid workers, not the individual. Employment Agreement is binding on the parties so that if it is not carried out by one of the parties, the injured party has no right to make demands pedestal. PKWT registration and list freelance worker are obliged if it is not implemented then be PKWTT. Thus, its function is to control the government in order not employed continuously and the type and nature of the work in accordance with applicable regulations. Registration List freelance worker can be predicted will be difficult to implement in practice, because a worker may be alternated since the pay is based on the presence of workers which applies the principle of "no work no pay" that applies in the law of colonial individualistic. 
This means that employers can at any time not hire workers because their performance is deemed not good enough. Workers also cannot work with a wide range of possibilities such as illness, while health insurance does not exist because of particular reasons. When going back to work is not necessarily mask employers will accept it, because there is no clear work bonds and are not covered by the Labor Law. It is certainly not going to realize justice in PKHL working relationship, both the employers and workers.

Funds must be spent by employers to social security (such as accident insurance, health insurance, life insurance and retirement and pension insurance) and severance pay when incurred termination would not exist if the employer uses a system of contract labor included freelance. Wages of daily paid workers are not stipulated in the provisions of Ministerial Decree No. Kep.100/Men/VI/2004. Precisely, workers are paid based on daily wages. The employer can decide a number of wages for workers. Given the position of the workers are not balanced with employers regarding economic and social conditions, the workers cannot determine the size of a decent wage. Therefore, it is expected to be an important role of government in order to establish the amount of the minimum wage.

\section{Conclusion}

The rights of non-permanent employees, in general, can be seen in the 1945 Constitution and Law No. 13 of 2003 on Labour, but not all the rights of workers contained in two pieces of legislation that can be enjoyed by non-permanent employees considering they have a special working relationship, and in contrast to permanent workers. Similarly, the rules relating to non-permanent employees are specifically contained in Ministerial Decree No. Kep.100/Men/VI/2004. The issue is a legal product in the form of a ministerial decree was found to have several drawbacks that have not been able to provide adequate legal protection for non-permanent employees. The government must, therefore, create new legal policies for the benefit of non-permanent employees with more protection. Instead of the non-permanent employees, they must also be willing to upgrade their quality in order to understand the things that become rights and obligations.

\section{Acknowledgements}

This work is supported by the University of North Sumatera under the BP-State research program. We thank USU for financial support.

\section{References}

- Abdul Ahad Riki, Mahendra Putra Kurnia, Erna Susanti, "Tinjauan Hukum terhadap Pelaksanaan PerlindunganHukum Terhadap Tenaga Kerja Harian Lepas (Studi pada CV. Dwijaya Bhakti Rayon Kabupaten Penajam Paser Utara), Jurnal Beraja Niti, ISSN 23374608, volume 3 Nomor 2(2014).

- Agusmidah, 2011, Dilematika Hukum Ketenagakerjaan, Tinjauan Politik Hukum, Jakarta: PT. Sofmedia.

- Christina NM Tobing, "Rekonstruksi Perjanjian Kerja Harian Lepas dalam Hukum Ketenagakerjaan Berbasis Keadilan", Disertasi, Fakultas Hukum Universitas Islam Sultan Agung (Unisula), Semarang, 2016 hlm. 2016.

- Gerry Silaban dan Salomo Perangin-angin, 2008, Hak dan Atau Kewajiban Tenaga Kerja dan Pengusaha/Pengurus yang Ditetapkan Dalam Peraturan Perundangan Keselamatan dan Kesahatan Kerja, Medan: USU Press.

- http://hukum.studentjournal.ub.ac.id/index.php/hukum/article/viewFile/504/4/493 http://ojs.unud.ac.id/index.php/kerthasemaya/article/download/21911/14540

- Imam soepomo,1974, Hukum Perburuhan Bidang Hubungan Kerja, Cet. II, Djembatan, Jakarta. 
- Materi Pelatihan Hakim Pengadilan Hubungan Industrial, Kurikulum untuk Hakim Pengadilan Hubungan Industrial, Mahkamah Agung RI dan ILO, Mega Mendung-Bogor, Maret 2013,

- Persen Pekerja Sawit Berstatus Buruh Lepas, dalam: https://www.jurnalasia.com/bisnis/agribisnis/70-persen-pekerja-sawit-berstatus-buruhlepas/

- Susi Hadiyati dan Adi Cilik Pierewan, http://www.e-jurnal .com /2016/02/strategibertahan-hidup-buruh-harian.html

- Schclarek, A. (2004). Debt and economic growth in developing and industrial countries. Lund University Department of Economics Working Paper, 2005, 34.

- Stephen N. 2014, Ghana's debt distress threatens economic livelihoods of itscitizens.http://www.ghanaweb.com/GhanaHomePage/features/columnist. 